\title{
A Brief Review on Effect of Continuous Application of Fertilizers and Manures on Soil Physical Properties, Nutrient Uptake, Growth and Yield of Rice on Chromustert
}

\author{
Challa Venu Reddy*, Alok Tiwari, K. Tedia, Anil Verma and R.R. Saxena \\ IGKV (Raipur), Chattishgarh, India \\ *Corresponding author
}

\section{A B S T R A C T}

Keywords

Fertilizers, Manures, Physical properties, Growth, Yield, Rice.

Article Info

Accepted:

04 September 2017

Available Online:

10 November 2017
This review pertinent to the present investigation entitled, "Effect of continuous application of fertilizers and manures on soil physical properties, nutrient uptake, growth and yield of rice on Chromustert" has been reviewed in this chapter under the following heads: I. Effect of continuous application of inorganic fertilizer and organic manures on soil physico-chemical properties. II. Effect of continuous application of inorganic fertilizer and organic manures on soil nutrient status. III. Effect of continuous application of inorganic fertilizer and organic manures on growth parameters, yield and nutrient uptake.

\section{Introduction}

Effect of continuous application of inorganic fertilizer and organic manures on soil physico-chemical properties

\section{Bulk density}

Prasad and Singh (1980) reported that continuous use of FYM and NPK fertilizers over a period of 20 years helped in maintaining and improving the physical properties and organic carbon content of an acidic red loam soil, while the application of fertilizer nitrogen alone slightly deteriorated soil physical properties. Treatment effect on bulk density of soil was not significant, although in some of the treatments there was a tendency for the bulk density to increase from the initial level. The lowest bulk density was found in FYM+PK $\left(1.29 \mathrm{Mg} / \mathrm{m}^{3}\right)$ plot. A decline in bulk density due to the application of organic matter has been reported by Pandey et al., (1985).

Rabindra et al., (1985) found that the combined application of in-organics and organic material maintained and improved the physical condition of the soil and the productivity. Urea as the organic sources of fertilizer $\mathrm{N}$ was found to be better than other sources tried in maintaining the soil physical condition and productivity. The lowest bulk density was found under normal dose of NPK+ 25t FYM ha ${ }^{-1}$ and the highest bulk density was found in no manure (control). 
Studies conducted by Sharma and Sharma (1994) also revealed that there was a reduction in soil bulk density from the initial value due to increased fertilizer levels or FYM application, but in un manured plots bulk density remained stable around initial value.

Bellakki and Badanur (1997) reported that in situ incorporation of sun hemp for ten years from 1984-94 reduced the bulk density as compared with fertilizer application.

Premi (2003) and Mandal et al., (2003) reported that combined use of organic and inorganic sources of $\mathrm{N}$ decreased the bulk density of soil.

Bajpai et al., (2006) found that incorporation of organic sources considerably decreased the bulk density of the soil. The lowest bulk density was observed in the 50 per cent NPK through fertilizer +50 percent $\mathrm{N}$ through green manure treatment $\left(1.43 \mathrm{Mg} \mathrm{m}^{-3}\right)$, while the highest was noted in control plot $(1.56 \mathrm{Mg}$ $\left.\mathrm{m}^{-3}\right)$.

Chaudhary and Thakur (2007) revealed that FYM along with fertilizers had a positive response on penetration resistance and bulk density of soil.

Hati et al., (2007) suggested that the bulk density was reduced significantly with the $100 \%$ NPK + FYM treatment over all other treatments.

Bandyopadhyay et al., (2010) reported that conjunctive use of recommended dose of fertilizer and farmyard manure (NPK + FYM) resulted in significant $(\mathrm{P}<0.05)$ decrease of bulk density.

Katkar et al., (2012) noticed that the application of farm yard manure @ 10 tonnes/ha recorded significant decrease in bulk density as compared to $100 \%$ NPK and $150 \%$ NPK through chemical fertilizer without organics.

\section{Hydraulic conductivity}

Prasad and Singh (1980) found that in acidic red loam soil, the use of FYM @ 20 t/ha with inorganic fertilizer providing $\mathrm{P}$ and $\mathrm{K}$ had significantly higher hydraulic conductivity $\left(2.5 \mathrm{~cm} \mathrm{hr}^{-1}\right)$ over the control and after 20 years it is similar to initial value $\left(2.0 \mathrm{~cm} \mathrm{hr}^{-1}\right)$.

Bhatia and Shukla (1982) reported that nitrogenous and phosphate fertilizers have a tendency to increase hydraulic conductivity probably due to increased large pores in soil.

Mishra and Sharma (1997) reported that in calcareous silt loam soil, increasing level of fertilizer dose significantly increase the hydraulic conductivity. Among the application of inorganic fertilizer, 100\% NPK alone treated plot recorded $\left(14.7 \times 10^{-7} \mathrm{~m}\right.$ $\left.\mathrm{sec}^{-1}\right)$ reduced hydraulic conductivity $(23.7 \mathrm{x}$ $10^{-7} \mathrm{~m} \mathrm{sec}^{-1}$ ).

The combined application of FYM and fertilizers has favourable effect on the hydraulic conductivity of soil. Favourable treatment effects on aggregation and BD were well reflected in their effect on hydraulic conductivity.

Selvi et al., (2005) observed that different treatment effects on aggregation and bulk density were well reflected on hydraulic conductivity. Increasing levels of fertilizers significantly increased hydraulic conductivity. Combined application of FYM and NPK also resulted in significantly highest hydraulic conductivity than NPK application. Highest hydraulic conductivity was noted in 100 percent $\mathrm{NPK}+\mathrm{Zn} \mathrm{SO}$ treated plot $(1.99 \mathrm{~cm}$ $\left.\mathrm{hr}^{-1}\right)$ and lowest was found in control $(1.44 \mathrm{~cm}$ $\mathrm{hr}^{-1}$ ) plot. 
Katkar et al., (2012) revealed that the direct addition of organic matter through farm yard manure and increase in root biomass which helped in growth and development of soil micro-organisms cause beneficial effect on improvement in mean weight diameter, available water holding capacity and hydraulic conductivity.

\section{Infiltration rate}

Acharya et al., (1988) studied the infiltration rate and cumulative infiltration rate (for 180 $\mathrm{min}$ ), which showed a greater variation owing to the imposition of different treatments. 100 per cent NPK + FYM and 150 per cent NPK showed the highest infiltration rate of 18.9 and $18.4 \mathrm{~cm} \mathrm{hr}^{-1}$ respectively.

More (1994) on sodic Vertisol under ricewheat rotation observed that application of FYM; organic waste and manures decreased soil $\mathrm{pH}$ but increased the infiltration rate.

Bellaki and Badanur (1997) found that the improvement in infiltration rate of Vertisol in $50 \% \mathrm{RDF}+50 \% \mathrm{~N}$ applied either through green manure or FYM in Sorghum-Safflower crop rotation over 10 year under dry land condition. Sesbania GM and Mungbeen residue incorporation resulted in reduction of bulk density and increase in soil aggregation which in turn increased the infiltration rate and percolation rate in rice-wheat cropping system (Mandal et al., 1999).

Harne (2001) observed that the combined application of FYM @ $3.37 \mathrm{t} \mathrm{ha}^{-1}+55 \mathrm{Kg} \mathrm{N}$ and GM@1.9 t ha ${ }^{-1}+40 \mathrm{Kg} \mathrm{N}$ showed significantly increased infiltration rate i.e. 3.10 and $3.60 \mathrm{~mm}^{-1}$ day $^{-1}$ respectively, over general recommended dose treated plot $(2.50$ $\mathrm{mm}$ day $\left.^{-1}\right)$. This indicates that in Vertisol, addition of coarse organic matter with inorganic fertilizers increased the basic infiltration rate. This higher infiltration rate could be associated with decreased bulk density and increased porosity of Vertisol.

Gangwar et al., (2002) reported that in ricewheat system, there was tremendous increase in infiltration rate from $0.58 \mathrm{~mm} \mathrm{hr}^{-1}$ of initial value to $1.97 \mathrm{~mm} \mathrm{hr}^{-1}$ with the addition of Sesbania seaban lopping @ $5 \mathrm{t} \mathrm{ha}^{-1}$ year as green manure incorporation in sandy loam soil. This higher infiltration rate could be associated with decreased bulk density and increased porosity of Vertisol.

Marathe and Bharambe (2005) noted that application of recommended dose of fertilizer had higher infiltration rate $\left(1.27 \mathrm{~cm} \mathrm{hr}^{-1}\right)$ and cumulative infiltration $(108 \mathrm{~mm})$ over control $\left(0.80 \mathrm{~cm} \mathrm{hr}^{-1}\right.$ and $\left.63 \mathrm{~mm}\right)$.

Sharma (2005) reported that green manuring with sesbania or green gram residues incorporation in combination with 100 per cent $\mathrm{N}\left(120 \mathrm{~kg} \mathrm{ha}^{-1}\right)$ treated plot recorded increased infiltration rate i.e. 2.21 and 2.19 $\mathrm{cm} \mathrm{hr}{ }^{-1}$ respectively, over the fallow plots $\left(2.13 \mathrm{~cm} \mathrm{hr}^{-1}\right)$. These treatments are pre-rice treatment and observations were recorded at the time of wheat sowing. Residue incorporation resulted in reduction in $\mathrm{BD}$ and increase in soil aggregation, which in turn increased infiltration, percolation rate and hydraulic conductivity of soil.

Bajpai et al., (2006) observed that integrated nutrient management in rice wheat system had marked influence on infiltration rate. However the infiltration rate was significantly higher $\left(1.30 \mathrm{~cm} \mathrm{hr}^{-1}\right)$ in 100 per cent recommended NPK through fertilizer in rice and wheat, over the control plot $(0.85 \mathrm{~cm}$ $\left.\mathrm{hr}^{-1}\right)$.

Tripti (2013) revealed that the application of organic manure along with chemical fertilizers had marked influence on infiltration rate. The higher infiltration rate in treatment 
$100 \%$ NPK + FYM and $50 \%$ NPK + GM as compared to other treatments. This indicates that the higher infiltration rate could be associated with decreased bulk density and increased porosity of the soil.

\section{Soil aggregates}

Mishra and Sharma (1997) revealed that the interaction effect of fertilizer and organic manures was not significant but its values indicated that combined application of fertilizer with FYM increased per cent fine $(11.4 \%)$ and coarse aggregate (4.2\%) size, in calcarious silt loam soil over control plot i.e. $10 \%$ fine and $3.9 \%$ coarse aggregates.

Marathe and Bharambe (2005) reported that application of recommended dose of fertilizer in Vertisol soil of Nagpur have per cent water stable aggregates (WSA) more than $0.25,0.10$ $\mathrm{mm}$ and mean weight diameter (MWD) recorded 40.4, 74.0 and $0.286 \mathrm{~mm}$ as compared to control i.e., 34.1, 64.1 and 0.233 $\mathrm{mm}$, respectively.

Selvi et al., (2005) revealed that the continuous application of fertilizer (100\% NPK) showed significant increase in MWD and per cent WSA values from $0.703 \mathrm{~mm}$ and $82.3 \%$ as compared to $0.696 \mathrm{~mm}$ and $72.6 \%$ in control. They further reported that increase in aggregate stability as compared to control due to balanced dose of fertilizer on soil structure may be because of the role played by phosphate ions in binding of soil particles (Sivasamy, 1982) or due to large amount of residues produced in the fertilized plots resulting in aggregate formation.

Hati et al., (2007) studied that the MWD and $\%$ WSMA in $100 \%$ NPK + FYM were significantly higher than in the other treatments. Fertilizer plus manure application (100\% NPK + FYM) increased by $35.3 \%$, while recommended rate of fertilizer application (100\% NPK) increased it by $17.6 \%$ compared to the control. The MWD in $100 \%$ NPK was significantly more than in control and $100 \% \mathrm{~N}$. This might be ascribed to higher organic matter content in the plots where NPK was applied alone or in conjunction with FYM.

Chakraborthy et al., (2010) observed that better aggregation was found with $100 \%$ NPK + farmyard manure, where macro aggregates were greater than $50 \%$ of total soil mass. Aggregation indices were positively and significantly correlated with soil organic carbon in 8 - $4 \mathrm{~mm}$ aggregates.

\section{Crack volume}

Dasog and Shashidhara (1993) studied the crack volume in a Vertisol under different crop covers and concluded that crack volume was highest in the plot under safflower (445 $\mathrm{m}^{2} \mathrm{ha}^{-1}$ ) followed by plots under wheat (353 $\left.\mathrm{m}^{2} \mathrm{ha}^{-1}\right)$ and chick pea $\left(310 \mathrm{~m}^{2} \mathrm{ha}^{-1}\right)$. The crack volume was highest in plots planted with safflower because of its deep rooting and efficient moisture extraction and least in fallow plot $\left(234 \mathrm{~m}^{3} \mathrm{ha}^{-1}\right)$. The moisture content affect crack volume, also supported by EI Abedine and Robinson (1971) showing that crack width is affected by length of the dry period and the crack depth is inversely related to moisture content.

Vishwambharrao (2005), reported that increasing dose of chemical fertilizers along with organic manures responsible for decrease in crack volume, whereas omission of chemical fertilizer plot much higher crack volume than optimal and sub optimal application of chemical fertilizer.

\section{pH}

Sheeba and Chellamuthu (2000) observed that the continued application of varying 
quantities of inorganic fertilizers and their combination with FYM over 22 years did not alter the $\mathrm{pH}$ appreciably.

Pothare et al., (2007) reported that all the soil properties such as $\mathrm{pH}$ were favorably influenced with the conjuctive use of organics and inorganics.

Highest values were observed in the treatment of $100 \% \mathrm{NPK}+10 \mathrm{t} \mathrm{FYM} \mathrm{ha}^{-1}$. In general among all the treatments 100\% NPK+FYM showed better result and control gave poorest results. Similar results were also observed by Agrawal et al., (2010).

Rajeswar et al., (2009) reported that all the pedons were neutral (7.4) to moderately alkaline (8.7) in reaction $(\mathrm{pH})$ in soils of Garikapadu of Krishna (A.P.). Lower $\mathrm{pH}$ values were recorded in the surface as compared to subsurface horizons.

Mohana Rao et al., (2013) reported that the $\mathrm{pH}$ of soil was not influenced statistically by various treatments.

The continuous use of manures and fertilizer, slightly lowered the $\mathrm{pH}$. Increased dose of fertilizer decreased the $\mathrm{pH}$. Sharma et al., (2007) also reported non-significant results in soil $\mathrm{pH}$ after 31 year of experimentation.

\section{Electrical conductivity}

Pothare et al., (2007) reported that all the soil properties such as electrical conductivity (EC) were favorably influenced with the conjuctive use of organics and inorganics. Highest values were observed in the treatment of $100 \%$ NPK $+10 \mathrm{t} \mathrm{FYM} \mathrm{ha}^{-1}$. The results were conformity by the findings of Agrawal et al., (2010).

Rajeswar et al., (2009) reported that the EC values varied from 0.10 to $0.32 \mathrm{dSm}^{-1}$ in the soils of Garikapadu, Krishna (A.P.).

\section{Organic carbon}

Tiwari et al., (2002) reported from the experiment conducted on Typic Haplustalf: that the continued application of fertilizers alone also helped in increasing the organic carbon content of soil, which could be attributed to higher contribution of biomass of soil in the form of crop stubbles and residues.

Fan et al., (2005) observed that the combination of organic and inorganic fertilization enhanced the accumulation of soil organic carbon and maintained the highest productivity. Hati et al., (2007) stated that the balanced application of inorganic fertilizer and organic amendments greatly influenced the accumulation of organic matter in soil.

Pothare et al., (2007) reported that all the soil properties such as organic carbon were favorably influenced with the conjunctive use of organic and inorganic. Highest values were observed in the treatment of $100 \%$ NPK +10 $\mathrm{t}$ FYM ha ${ }^{-1}$. Similar results were also experienced by Agrawal et al., 2010.

Katkar et al., (2012) described that the organic manures (FYM) along with recommended dose of fertilizers found to be viable option in increasing soil organic carbon, nutrient turn over, enhancing microbial biomass, thereby improvement in availability of nutrients in soil, maintenance of soil quality and achieving the sustainable productivity of sorghum and wheat for long run in rainfed as well as irrigated moisture regimes.

Moharana et al., (2012) reported that the continuous application of FYM either alone or in combination with NPK resulted in considerable accumulation of total SOC in 10-15 CM soil layer than unfertilized control plots. Further they concluded that for sustainable crop production and maintaining 
Soil Quality, input of organic manure like FYM is of major importance and should be advocated in the nutrient management of intensive cropping system for improving chemical and biological properties of soil.

\section{Effect of continuous application of inorganic fertilizer and organic manures} on soil nutrient status

Yashpal et al., (1993) studied that larger buildup in available phosphorus with green manure and crop residue may be attributed to the influence of organic manure in increasing the labile phosphorus in soil through complex of cations like $\mathrm{Ca}^{2+}$ and $\mathrm{Mg}^{2+}$ which are mainly responsible for the fixation of phosphorus in calcareous soil.

Gupta (2000) reported the available N, P, and $\mathrm{K}$ status in soil also improved with the individual application of fertilizer nutrients but still higher build-up of available N, P, and $\mathrm{K}$ was noted in FYM/Compost treated plots. Sharma et al., (2000) revealed that the favorable soil conditions under compost and crop residue might have helped in the mineralization of soil $\mathrm{N}$ leading to the buildup of higher available nitrogen.

Usman (2000) reported that effects of organic sources alone on the growth of rice plant and its growth parameters were not significant due to their slow supply of nutrients.

These growth parameters were improved when supplemented with mineral fertilizers at the rate of 100-75-60 kg N, $\mathrm{P}_{2} \mathrm{O}_{5}$ and $\mathrm{K}_{2} \mathrm{O}$ ha ${ }^{-1}$ along with organic materials. Pothare et al., (2007) reported that all the soil properties such as available NPK were favorably influenced with the conjuctive use of organics and inorganics. Highest values were observed in the treatment of $100 \% \mathrm{NPK}+10 \mathrm{t}$ FYM $\mathrm{ha}^{-1}$. The results were in agreement with the finding of Agrawal, et al., 2010.
Kumar and Prasad (2008) suggested that the increase in available nitrogen due to incorporation of organic materials might be also attributed to the enhanced multiplication of microbes by the incorporation of crop residue and compost for the conversion of organically bound $\mathrm{N}$ to inorganic form.

Pandey et al., (2009) revealed that there was buildup of available $\mathrm{N}, \mathrm{P}$ and $\mathrm{K}$ with conjoint use of chemical fertilizers with compost and crop residue incorporation in soil. Addition of different organic materials increased the organic carbon and slightly decreased in soil $\mathrm{pH}$.

Karmakar et al., (2011) reported that the application of $50 \%$ NPK, $25 \% \mathrm{~N}$ through FYM, green manure and blue green algae increased the organic carbon, available $\mathrm{N}, \mathrm{P}$ and $\mathrm{K}$ of soil. Improvement in soil physico chemical properties might be due to direct application of organic manures along with chemical fertilizer and increased growth of the plant resulted in higher root biomass and its recycling.

Kumar, et al., (2012) observed that the longterm integrated nutrient management through FYM in 50\% RDF + 50\% FYM treatment had resulted in highest available $\mathrm{N}, \mathrm{P}$ and $\mathrm{K}$. Walia et al., also reported that long-term integrated nutrient management in rice wheat cropping system increased the availability of NP and K nutrients.

Verma et al., (2012) concluded that the balanced use of fertilizer alone or conjoint use of inorganics with organics resulted in a significant build- up of organic carbon and available N,P and $\mathrm{K}$ over three decades leading to sustained soil fertility and productivity.

Tilahum Tadesse et al., (2013) concluded that the integrated use of farmyard manure and 
inorganic fertilizers was found to improve the soil total $\mathrm{N}$ and available P. Moreover, the use of FYM significantly increased soil organic matter and available water holding capacity but decreased the soil bulk density, creating a good environment for growth and development of the rice crop.

Effect of continuous application of inorganic fertilizers and organic manures on nutrient content and uptake, growth parameters and yield

Sharma and Sharma (1994) reported that the application of FYM @ $30 \mathrm{Kg} \mathrm{ha}^{-1}$ with $90 \mathrm{Kg}$ $\mathrm{N} \mathrm{ha}^{-1}$ through urea resulted in more number of spikelet per panicle in the rice crop and ultimately gave significantly higher yield of rice crop, while due to residual effect of previously applied FYM increased yield by 8 percent additionally in the succeeding crop as compared to control (Sharma and Mishra, 1990).

Gupta et al., (1995) reported that application of organic manures like FYM, rice husk, Saw dust and green manures in rice increased grain yield of rice - wheat cropping system. An increase in the productivity of rice - wheat sequence was reported from 4.35 to $8.40 \mathrm{t} \mathrm{ha}^{-1}$ in control and with green manuring with Dhaincha, respectively (Mahapatra and Sharma, 1995). Application of FYM to rice increased the grain yield of both rice and wheat over control showing marked residual effect on soil fertility (Brar et al., 1995).

A significant increase in grain and straw yields of rice over control by 5.90 and 6.36 percent was obtained with the application of $10 \mathrm{t} \mathrm{ha}^{-1}$ FYM to rice crop (Singh et al., 1996).

Findings of Long-term fertilizer experiments conducted at various locations in India, indicated that 25 to $50 \%$ nitrogen needs of rice can be substituted through FYM or green manure without any detrimental effect on the productivity of rice - wheat cropping system (Hedge, 1998).

FYM @ $3 \mathrm{t} \mathrm{ha}^{-1}$ in combination with inorganic fertilizer gave higher grain yield $3.36 \mathrm{t} \mathrm{ha}^{-1}$ as compared to control plot $(1.49 \mathrm{t}$ $\mathrm{ha}^{-1}$ ) in rice crop, which also increased the nutrient uptake, Bat et al., (1993), whereas, the grain yield, $\mathrm{N}, \mathrm{P}$ and $\mathrm{K}$ uptake were highest with 5 tons FYM $+50 \mathrm{Kg} \mathrm{N}$ than 100:50:50 kg NPK ha ${ }^{-1}$ and $10 \mathrm{t} \mathrm{FYM} \mathrm{ha}^{-1}$ only (Babu and Reddy, 2000).

Swarup and Yaduvanshi (2000) reported that in 3 years experiment there was no significant difference in yield at first year with the application of 100 percent NPK + GM $(0.72$ percent N), 150 percent NPK and 100 percent $\mathrm{NPK}+\mathrm{FYM} @ 10 \mathrm{t} \mathrm{ha}^{-1}$ yield 5.57, 6.25 and $6.12 \mathrm{t} \mathrm{ha}^{-1}$, respectively.

During next year 100 percent NPK and GM and FYM gave significant better yield than 150 per cent NPK whereas, 100 percent NPK, 110 percent NPK and 50 percent NPK + GM yielded 5.60, 5.80 and $6.50 \mathrm{t} \mathrm{ha}^{-1}$ respectively, which is more or less similar.

Kumar et al., (2001) reported that the application of $100 \%$ NPK along with FYM @ $20 \mathrm{t} \mathrm{ha}^{-1}$ increased the grain yield of rice significantly over the control. Similar trends were also found in straw yield.

Manna et al., (2001) revealed that the increase in nutrient uptake may be due to an increase in available $\mathrm{N}, \mathrm{P}$ and $\mathrm{K}$ contents in the soil and improved soil structure for higher uptake of nutrients.

Sharma and Bali (2001) studied that the incorporation of organic sources of nutrition, the grain yield of control significantly increased to the tune with compost, crop 
residue and compost + crop residue, respectively. Compost or crop residue resulted in a small increase in grain yield but their combination was superior to either of them.

Sharma and Sharma (2002) reported that NPK + FYM increased 38 to 45,7 to 10 and 25 to $42 \mathrm{Kg} \mathrm{ha}^{-1} \mathrm{~N}, \mathrm{P}$ and $\mathrm{K}$ uptake, respectively over $\mathrm{N}$ alone.

Ghosh and Singh (2003) evaluated the effect of conjoint use of farmyard manure and nitrogen on rice - wheat system in Uttaranchal mid-hill soils.

They observed that grain and straw yields increased with increasing rates of FYM and N fertilizer for both the crops, and the highest yields were obtained with $15 \mathrm{tha}^{-1} \mathrm{FYM}+60$ or $80 \mathrm{Kg} \mathrm{ha}^{-1} \mathrm{~N}$.

Phogat et al., (2004) found that the total productivity of rice - wheat system increased significantly with green manure and FYM compared to control and with FYM over green manure in all the years.

Singh and Agarwal (2004) reported that the application of $10 \mathrm{t} \mathrm{ha}^{-1}$ FYM in rice - wheat cropping system resulted in significantly higher $\mathrm{N}, \mathrm{P}$ and $\mathrm{K}$ uptake compared with control.

Chaudary and Thakur (2007) have documented that the application of FYM in conjunction with chemical fertilizers had stimulatory effect on yield irrespective of crops and season: however, quantum of yield was much higher when applied in Kharif.

Pandey et al., (2009) indicated that the integrated effect of compost and crop residue with fertilizers at any level of NPK resulted in maximum yield. Integrated effect of chemical fertilizers with organic manure and crop residue also augmented $\mathrm{N}, \mathrm{P}$ and $\mathrm{K}$ uptake over control. Urkurkar et al., (2010) proved that over 16 years of the study period, highest rice and wheat yield was obtained when 50\% of $\mathrm{N}$ was supplied through green manure in conjunction with $50 \%$ of NPK through inorganic fertilizers $(50 \%$ recommended dose of fertilizer+ $50 \% \mathrm{~N}$-green manure) than other treatments.

Karmakar et al., (2011) reported that the application of 50\% NPK through chemical fertilizers along with $25 \% \mathrm{~N}$ through FYM, green manuring and blue green algae recorded the highest plant height with effective tillers $\mathrm{m}^{-2}$ and LAI which was at par with $100 \%$ $\mathrm{NPK}$ and $50 \% \mathrm{~N} \mathrm{FYM} \mathrm{+} \mathrm{GM} \mathrm{+} \mathrm{BGA} \mathrm{but}$ significantly superior to control and completely inorganically and organically fertilized plots.

Further they concluded that the integrated use of chemical fertilizer (50\% RDF), FYM (25\% $\mathrm{N}$ ), green manure and blue green algae resulted in maximum yield and better $\mathrm{N}, \mathrm{P}$ and $\mathrm{K}$ uptake.

Islam Fakhrul et al., (2013) revealed that the higher levels of yield attributes and N, P, K and $\mathrm{S}$ concentration in grain and straw were recorded in combined application of fertilizer and manure compared to chemical fertilizer alone.

Priyanka et al., (2013) concluded that higher level of fertilizer and FYM significantly influenced the growth characters, nutrient content and yield of rice.

Singh et al., (2013) reported that the addition of organic amendments like FYM, BGA and Azolla in integrated manner with chemical fertilizers produced higher quantity of grain and the seed quality was also more superior to those obtained in solo chemical fertilizer application and control treatments. 


\section{References}

Acharya, C.L., Bisnoi, S.K., Yaduvanshi, H.S. 1988. Effect of long-term application of fertilizers and organic and inorganic amendments under continuous cropping on soil physical and chemical properties in an Alfisol. Indian J. Agric. Sci 58: 509-516.

Agrawal, M., Ram, N. and Shri Ram. 2010. Longterm effect of inorganic fertilizers and manure on physical and chemical properties of soil after 35 years of continuous cropping of ricewheat. Pantnagar Journal of Research. 8(1): 76- 80.

Babu, B.T.R. and Reddy, V.C. 2000. Effect of nutrient sources on growth and yield of direct seeded rice. Crop - Research Hissar. 19 (2): 189 - 193.

Bajpai, R. K., chitale, S., Upadhyay, S.K. and Urkurkar, J.S. 2006. Long-term studies on soil physico-chemical properties and productivity of rice - wheat system as influenced by integrated nutrient management in Inceptisol of Chhattisgarh. Journal of the Indian Society of Soil Science 54 (1): 24-29.

Bandyopadhyay, K.K., Mishra, A.K., Ghosh, P.K., and Hati, K.M. 2010. Effect of Integrated Use of Farmyard Manure and Chemical Fertilizers on Soil Physical Properties and Productivity of Soybean. Soil \& Tillage Research 110 (1): 115-125.

Bellaki, M.A. and Badanur, V.P. (1997). Longterm effect of integrated nutrient management on properties of Vertisols under dry land condition. Journal of the Indian Society of Soil Science. 45,438-442.

Bhatia, K.S. and Shukla, K.K. 1982. Effect of continuous application of fertilizer and manure on some physical properties of eroded Alluvial Soil. J. Indian Soc. Soil Sci. 30(1):33-36.

Brar, B.S., Dhillon, N.S. and Chand, M. 1995. Effect of farmyard manure application on grain yield and uptake and availability of nutrients in rice - wheat rotation. Indian Journal of Agricultural Sciences. 65(5): 350-353.

Chaudhary, S.K. and Thakur, R.B. 2007. Efficient farm yard management for sustained productivity of rice (Oryza sativa) - wheat
(Triticum aestivum) cropping system. Indian Journal of Agricultural Sciences 77(7): 443-444.

Dasog, G.S. and Shashidhara, G.B. 1993. Dimension and volume of cracks in a vertisol under different crop covers. Soil Science 156(6): 424-428.

EI Albedine and Robinson, G.H. 1971. A study on cracking in some Vertisols of Sudan. Geoderma 5: 229-241.

Fakhrul Islam, M.M.AL., Asaduzzaman Khan, Md., Fazle Bari, A.S.M., Hosain, M.T and Sabikunnaher. 2013. Effect of fertilizer and manure on growth, yield and grain nutrient concentration of Boro Rice (Oryza Sativa L.) under different water management practices. The Agriculturists, 11(2): 44-51.

Fan, T., Stewart, B.A., William A. Payne, Wang Yong, Junjie Luo, Yufeng Gao. 2005. Long term fertilizer and water availability effects on cereal yield and soil chemical properties in North west China. Soil. Sci. Soc. Am. J. 69: 842 - 855.

Gangwar, K.S., Sharma, S.K., Sharma, G.C. and Tomar, R.K. 2002. Integrated nutrient management in alley cropping in sustainable upland rice-wheat system. $J$. Farming systems Research and development. 8:1 \& 2, 15-18.

Ghosh, B.N. and Singh, R.D. 2003. Effect of conjoint use of farmyard manure and nitrogen on rice (Oryza sativa) - Wheat (Triticum aestivum) system in Uttaranchal mid-hill soils. Indian Journal of Agricultural Sciences. 73 (12): 680-683.

Gupta, N. C. 2000. Impact of Long term Manure and fertilizer Application on Nutrient Status and other Properties in Alluvial Soils of Bihar. Rajendra Agricultural University.

Gupta, R.P., Aggarwal, P. and Kumar, S. 1995. All India Coordinated research project on improvement of soil physical conditions to increase agricultural production of problematic areas. Highlights of Research, S.P.C. Bulletin No. 8: 31-43.

Harne, R.B. 2001. Influence of integrated use of organics to sustain productivity of rice. M.Sc. (Ag.) Thesis, Dept. of Soil Sci. IGAU, Raipur

Hati, K.M., Swarup, A., Dwivedi, A.K., Mishra, A.K., and Bandyopadhyay, K.K. 2007. 
Changes in Soil Physical Properties and Organic Carbon Status at the Topsoil

Hedge, D.M. 1988. Integrated nutrient management effect on rice (Oryza sativa) Wheat (Triticum aestivum) system productivity in sub humid ecosystem. Indian Journal of Agricultural Sciences 68 (3): 144-148.

Karmakar, S., Surya Prakash., Rakesh Kumar., Agrawal, B.K., Devkant Prasad and Rajeev(2011). Horizon of a Vertisol of Central India after 28 Years of Continuous Cropping, Fertilization and Manuring. Agriculture, Ecosystems and Environment 119 (1-2): 127-134.

Katkar, R.N., Kharche, V.K., Sonune, B.A., Wanjari, R.H., and Muneshwar singh 2012. Long term effect of nutrient management on soil quality and sustainable productivity under sorghum- wheat crop sequence in vertisol of Akola, Maharashtra. Agropedology, 22(2), 103-114.

Kumar, N., Verma, L.P., Singh, Room and Prasad, K. 2001. Soil Properties, nutrient uptake and productivity of rice under integrated nutrient management system. Ann. plant Soil Res. 3(1): 112 - 115.

Kumar, Vipin and Prasad, R.K. 2008. Integrated effect of mineral fertilizer and green manure on crop yield and nutrient availability under rice-wheat cropping system in calciotthents. Journal of the Indian Society of Soil Science, 56: 209-214.

Kumar.2011. Effect of green manuring and biofertilizers on rice production.

Oryza 48(4):339-342.

Mahapatra, B.S. and Sharma, G.L. 1995. Effect of summer legumes on growth and yield of low land rice (Oryza sativa) - Wheat (Triticum aestivum) in rice - wheat system. Indian Journal of Agricultural Sciences. 65 (8): 557 - 561.

Mandal, U.K., Sharma, S.N., Singh, G. and Das, D.K. 1999. Effect of sesbania green manuring and green gram (Phasiolus radiatus) residue incorporation on physical properties of soil under rice (Oryza sativa) Wheat (Triticum aestivum) cropping system. Indian Journal of Agricultural Sciences 69: 615- 620.

Mandal, U.K., Singh, S., Victor, V.S. and Sharma,
K.L. 2003. Green manuring: its effect on soil properties and crop growth under ricewheat cropping system. European Journal of Agronomy 19 (2): 225-237.

Manna, M.C., Ghosh, P, K., Ghosh, B.N and Singh, K.N. 2001. Comparative effectiveness of phosphate - enriched compost and single super- phosphate on yield, uptake of nutrients and Soil quality under Soybean - wheat rotation. Journal of Agriculture Science, 137: 45-54.

Marathe, R.A. and Bharambe, R.R. 2005. Physical characteristics of vertisol as influenced by integrated nutrient management system under sweet orange. PKV R. J. 29(2): 179182.

Mishra, V.K. and Sharma, R.B.1997. Effect of fertilizer alone and in combination with manure on physical properties and productivity of Entisol under rice-based cropping system. J. Indian Soc. Soil Sci. 45(1):84-88.

Mohana Rao Puli, Katkar, R.N., Burla Srihari Rao and Jayalakshmi, M. 2013. Effect of long term fertilization on $\mathrm{pH}, \quad \mathrm{Ec}$ and Exchangeable $\mathrm{Ca}$ and $\mathrm{Mg}$ in vertisols under Sorghum - wheat cropping sequence. International Journal of Applied Biology and Pharmaceutical Technology. 4 (4): 431 $-433$.

Moharana, P.C., Sharma, B.M., Biswas, D.R., Dwivedi, B.S. and Singh, R.V. 2012. Longterm effect of nutrient management on soil fertility and soil organic pools under a 6 year-old Pearl millet - wheat cropping system in an Inceptisol of subtropical India. Field crops Research 136: 32-41.

More, S.D. 1994. Effect of farm wastes and organic manures on soil properties nutrient availability and yield of rice-wheat growth on sodic vertisol. J. Indian Soc. Soil Sci. 42(2): 253-256.

Nayak Tripti. 2013. Effect of organic and inorganic fertilization of Depth wise Distribution of Different forms of Phosphorus and potassium in vertisol. M.Sc. (Ag.) Thesis. Indira Gandhi Krishi Vishwavidyalaya, Raipur (C.G.).

Pandey, A.K., Vipin Kumar and Rajesh Kumar. 2009. Effect of long-term organic and inorganic nutrients on transplanted rice 
under rice - wheat cropping system. Oryza 46 (3): 209-212.

Pandey, S.P., Hari sankar and Sharma, V.K. 1985. Efficiency of some organic and inorganic residues in relation to crop yield and soil characteristics. Journal of the Indian Society of Soil Sciences 33(1): 179-181.

Phogat, S.B., Dahiya, I.S., Hooda, R.S., Sangwan, N.K. and Solanki, Y.P.S. 2004. Studies on residual effect of green manuring and farmyard manure for sustained productivity of rice - wheat cropping sequence and soil health under shallow ground water table conditions. Annals of Biology 20 (2): 161165.

Pothare, S., Rathod, P.K., Ravankar, H.N., Patil, Y.G., Yewale, A.C. and Pothare, D.2007. Effect of long-term fertilization in vertisols on soil properties and yield of sorghum wheat sequence. The Asian Journal of Soil Science 2(1): 74-78.

Prasad, B. and Singh, A.P. 1980. Changes in soil properties with long term use of fertilizer, lime and FYM. J. Indian Soc. Soil Sci.28(4): 465-468.

Premi, O.P. 2003. Integrated nutrient supply for sustainable rice production in acid alfisol. Indian Journal of Agricultural Research 37 (2): 132-135.

Rabindra, b., Narayan Swamy, G.V., Janardhan, N.A. and Shi vanagappa. 1985. Long range effect of manures and fertilizer on soil physical properties and yield sugarcane. $J$. Indian Soc. Soil Sci. 33(1): 704-6.

Rajeswar, M., Rao, C. S., Balaguravaiah, D. and Khan, M. A. A. 2009. Distribution of Available Macro and Micronutrients in Soils Garikapadu of Krishna District of Andhra Pradesh. J. Indian Soc. Soil Sci. 57(2): 210-213.

Selvi, D., Santhy, P. and Dhakshina moorthy, M. 2005. Effect of inorganics alone and in combination with farmyard manure on physical properties and productivity of vertic haplustepts under long-term fertilization. Journal of the Indian Society of $\quad$ Soil Science 53 (3): 302-307.

Sharma, A.R. and Mittra, B.N. 1990. Effect of organic materials and NPK level on growth and yield of rice. Indian Agriculturist. 34 (3): 169 - 175.
Sharma, G.D. and Sharma, H.L. 1994. Utilization of weed plants as organic manure under different methods of rice establishment. Indian. J. Agric. Sci. 64(3): 184 - 186.

Sharma, M., Mishra, B and Singh, R. 2007. Long term effect of fertilizers and manure on Physical and Chemical properties of Mollisol. J. Indian Soc. Soil. Sci. 55 (4): $523-524$.

Sharma, M.P. Bali, S.V. and Gupta, D.K. 2000. Crop yield and properties of inceptisol as influenced by residue management under rice - wheat cropping sequence. Journal of the Indian Society of Soil Science. 48:506509.

Sharma, S.K. and Sharma, S.N. 2002. Integrated nutrient management for sustainability of rice (Oryza sativa) - Wheat (Triticum aestivum) cropping system on soil fertility. Indian Journal of Agricultural Sciences. 70 (6): 357-359.

Sharma, S.N. 2005. Integrated nutrient management in rice - wheat cropping system. Fertilizer news, 50: 2, 53-58 and 61-64.

Sheeba, S. and Chellamuthu, S. 2000. Effect of long-term application of fertilizer and manures on soil properties of alluvial and laterite soils. Madras Agric J. 84 (1): 15-19.

Singh, A., Singh, R.D. and Awasthi, R.P. 1996. Organic and inorganic sources of fertilizers for sustained productivity in rice - wheat sequence on humid hilly soils of Sikkim. Indian Journal of Agronomy 41(2): 191194.

Singh, R. and Agarwal, S.K. 2004. Effect of organic manuring and nitrogen fertilization on productivity, nutrient- use efficiency and economic of wheat (Triticum aestivum). Indian Journal of Agronomy, 49 (1): 49 -52.

Singh, Y.N., Singh, K.K. and Sharma, S.K. (2013). Influence of crop nutrition on grain yield, seed quality and water productivity under two rice cultivation systems. Rice Science, 20(2): 129-138.

Swarup, A. and Yaduvanshi, N.P.S. 2000. Effect of integrated nutrient management on soil properties and yield of rice in alkali soils. Journal of Indian Society of Soil Science. 48 (2): 279-282.

Tilahum Tadesse, Nigussie Dechassa, Wondimu 
Bayu, Setegn Gebeyehu. 2013. Effect of farmyard manure and inorganic fertilizer application on soil physico - chemical properties and nutrient balance in rain-fed lowland rice ecosystem. American Journal of Plant Sciences. 4: 309 - 316.

Tiwari, Dwivedi, A.K and Dixit, P.R. 2002. Long - term influence of organic and inorganic fertilization on soil fertility and productivity of soybean - wheat system in vertisol. Journal of the Indian Society of Soil Science. 50 (4): 472-475.

Urkurkar, J.S, Tiwari, A., Shrikanth Chitale and Bajpai, R.K. 2010. Influence of long-term use of inorganic and organic manures on soil fertility and sustainable productivity of rice (Oryza sativa) and Wheat (Triticum aestivum) in Inceptisols. Indian Journal of Agricultural Sciences 80 (3): 208-212.

Usman,M. 2000.Effect of organic and inorganic manure on growth and yield of rice variety Basmati-2000. Faisalabad (Pakistan) 138.

Verma, G., Sharma, R.P., Sharma, S.P., Subehia, S.K. and Shambhavi, S. 2012. Changes in soil fertility status of maize - wheat system due to long-term use of chemical fertilizers and amendments in an alfisol. Plant Soil Environ, 58(12): 529-533.

Vishwambharrao, K.S. 2005. Effect of integrated nutrient supply system on soil physical and chemical environment and productivity of rice in Rice - Wheat cropping sequence. M.Sc. (Ag.) Thesis. Indira Gandhi Krishi Vishwavidyalaya, Raipur (C.G.).

Yashpal, Vig A.C. and Milap - Chand. 1993. Available soil phosphorus in relation to sesbania green manure incorporation in calcareous soils. Journal of the Indian Society of Soil Science 47: 72-80.

\section{How to cite this article:}

Challa Venu Reddy, Alok Tiwari, K. Tedia, Anil Verma and Saxena, R.R. 2017. A Brief Review on Effect of Continuous Application of Fertilizers and Manures on Soil Physical Properties, Nutrient Uptake, Growth and Yield of Rice on Chromustert. Int.J.Curr.Microbiol.App.Sci. 6(11): 91-103. doi: https://doi.org/10.20546/ijcmas.2017.611.012 